\title{
Video Article \\ Preparation and Testing of Impedance-based Fluidic Biochips with RTgill-W1 Cells for Rapid Evaluation of Drinking Water Samples for Toxicity
}

\author{
Linda M. Brennan ${ }^{1}$, Mark W. Widder ${ }^{1}$, Michael K. McAleer ${ }^{2}$, Michael W. Mayo ${ }^{2}$, Alex P. Greis ${ }^{2}$, William H. van der Schalie ${ }^{1}$ \\ ${ }^{1}$ U.S. Army Center for Environmental Health Research \\ ${ }^{2}$ Nanohmics, Inc.
}

Correspondence to: Linda M. Brennan at linda.m.brennan2.civ@mail.mil

URL: https://www.jove.com/video/53555

DOI: doi: $10.3791 / 53555$

Keywords: Environmental Sciences, Issue 109, Fish cells, impedance, sensors, biochip, water toxicity, ECIS, monolayer, field-portable

Date Published: 3/7/2016

Citation: Brennan, L.M., Widder, M.W., McAleer, M.K., Mayo, M.W., Greis, A.P., van der Schalie, W.H. Preparation and Testing of Impedance-based Fluidic Biochips with RTgill-W1 Cells for Rapid Evaluation of Drinking Water Samples for Toxicity. J. Vis. Exp. (109), e53555, doi:10.3791/53555 (2016).

\section{Abstract}

This manuscript describes how to prepare fluidic biochips with Rainbow trout gill epithelial (RTgill-W1) cells for use in a field portable water toxicity sensor. A monolayer of RTgill-W1 cells forms on the sensing electrodes enclosed within the biochips. The biochips are then used for testing in a field portable electric cell-substrate impedance sensing (ECIS) device designed for rapid toxicity testing of drinking water. The manuscript further describes how to run a toxicity test using the prepared biochips. A control water sample and the test water sample are mixed with pre-measured powdered media and injected into separate channels of the biochip. Impedance readings from the sensing electrodes in each of the biochip channels are measured and compared by an automated statistical software program. The screen on the ECIS instrument will indicate either "Contamination Detected" or "No Contamination Detected" within an hour of sample injection. Advantages are ease of use and rapid response to a broad spectrum of inorganic and organic chemicals at concentrations that are relevant to human health concerns, as well as the long-term stability of stored biochips in a ready state for testing. Limitations are the requirement for cold storage of the biochips and limited sensitivity to cholinesterase-inhibiting pesticides. Applications for this toxicity detector are for rapid field-portable testing of drinking water supplies by Army Preventative Medicine personnel or for use at municipal water treatment facilities.

\section{Video Link}

The video component of this article can be found at https://www.jove.com/video/53555/

\section{Introduction}

The overall goal was to develop a method for the cell seeding, storage and testing of fluidic biochips in the ECIS biosensor. The goal for the development of this biosensor was to meet US Army specifications for a field portable device that could detect possible contamination of drinking water supplies being used by soldiers. The requirements for the toxicity sensor were that it could detect a broad spectrum of toxic industrial compounds rapidly (within an hour) at concentrations relevant to human health, that the device be field-portable, and the biological components would have a shelf-life of at least nine months. Refrigeration, but not freezing, of perishable components was acceptable.

Historically, field portable water testing technologies with a biological component to them (such as antibodies, enzymes, or nucleic acids) have been analyte-specific ${ }^{1-3}$. The disadvantage to these types of biosensors is that they will only detect one type of chemical at a time. Multiple sensors are needed if it is suspected that more than one chemical is present. If a specific sensor is not in the test repertoire, chemical contaminants in the water could easily go undetected.

Broad-based toxicity sensors, on the other hand, have the potential to fill this technology gap. These usually have a cellular component to them ${ }^{4-8}$. The advantages of broad-based toxicity biosensors are that they can detect the presence of a wide array of chemical contaminants including mixtures and unknowns, in a relatively short period of time $e^{5,9,10}$.

The concept of using the measurement of electrical impedance of cell monolayers as a possible toxicity sensor, which is also known as electric cell-substrate impedance sensing (ECIS), was first described by Giaever and Keese ${ }^{11}$. Over the past two decades it has been shown to be a sensitive indicator of cell viability and cytotoxicity. Basically, the cell monolayer that is adhered to the electrodes on the biochips is exposed to high frequency and low voltage and amperage alternating current signal. The confluent monolayer of cells impedes the flow of electrons. When the integrity of the cell monolayer is compromised (such as when a toxic chemical is introduced), the ECIS sensor records a change in the electrical impedance ${ }^{11-14}$. Figure 1 illustrates the principle of ECIS in relation to the cell monolayer on the biochip. 


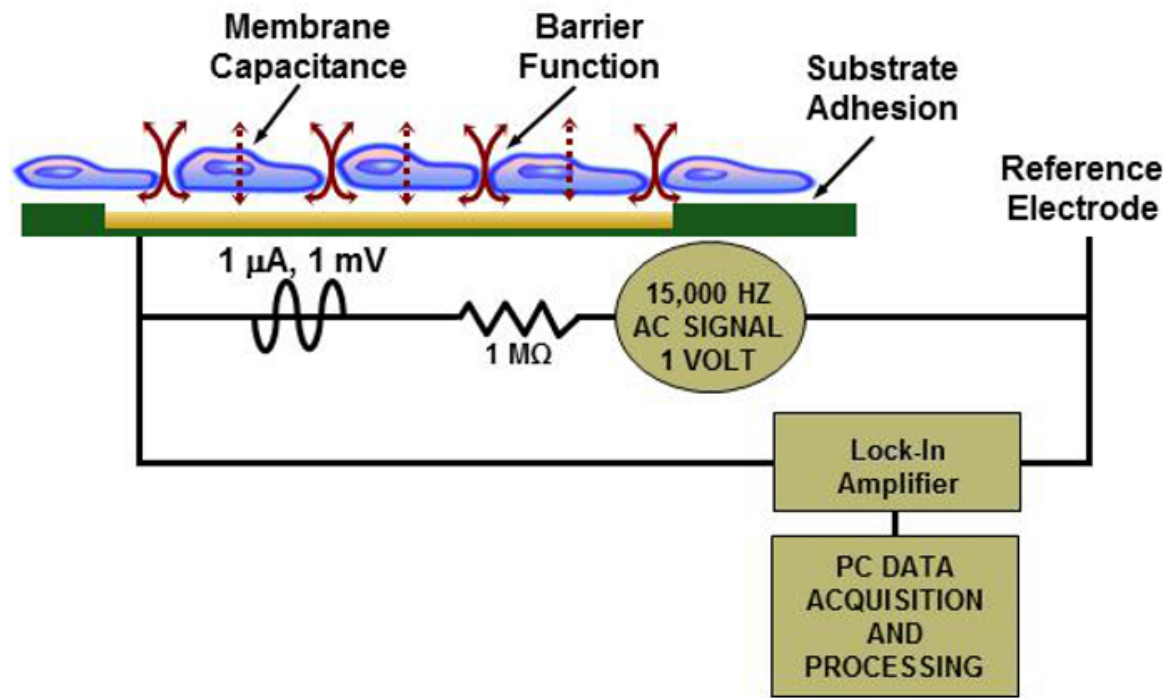

Figure 1: Principle of ECIS. Illustration of a cell monolayer on a biochip with simplified ECIS reader electrical schematic. Please click here to view a larger version of this figure.

Initially, mammalian cell lines were seeded in fluidic biochips and were used in the ECIS sensor technology described here ${ }^{12}$. These cells were not practical for field use, however, because they required frequent media changes, had a limited shelf-life, and required an artificial $\mathrm{CO}_{2}$ environment and a $37^{\circ} \mathrm{C}$ incubation temperature. It was discovered that a commercially available cell line derived from rainbow trout gill epithelial cells (RTgill W-1 cells) could be tested at room temperature at ambient $\mathrm{CO}_{2}$, formed a confluent monolayer in the biochips, could be stored at refrigerated temperatures, and had a rapid response (1 $\mathrm{hr}$ or less) to a broad spectrum of chemicals at concentrations relevant to human health $^{12}$. Applications of RTgill-W1 cells in toxicology, as well as in basic research, are reviewed by Lee et al. ${ }^{15}$

Methods for the seeding, storage and testing of fluidic biochips containing monolayers of RTgill-W1 cells on fluidic biochips in an ECIS biosensor are described here. The fluidic biochips can be stored for up to 9 months in a refrigerated state and can be shipped in a cold storage container, for testing of drinking water supplies. The accompanying ECIS readers, or test units, are shipped separately. The biochips have two components to them; an upper polycarbonate layer with two separate fluid channels, and a lower electronic layer that contains four electrode pads per channel for impedance sensing. There are 10 working electrodes per pad; each electrode is $250 \mu \mathrm{m}$ in diameter. The assembled biochips have gold electrode connections for acquiring impedance readings when inserted into the ECIS test unit. Each of the two enclosed fluidic U-shaped channels will hold $2 \mathrm{ml}$ of the RTgill-W1 cell suspension. Figure 2 shows a fluidic biochip in the ECIS reader with a magnification of a confluent cells on a single sensing electrode.

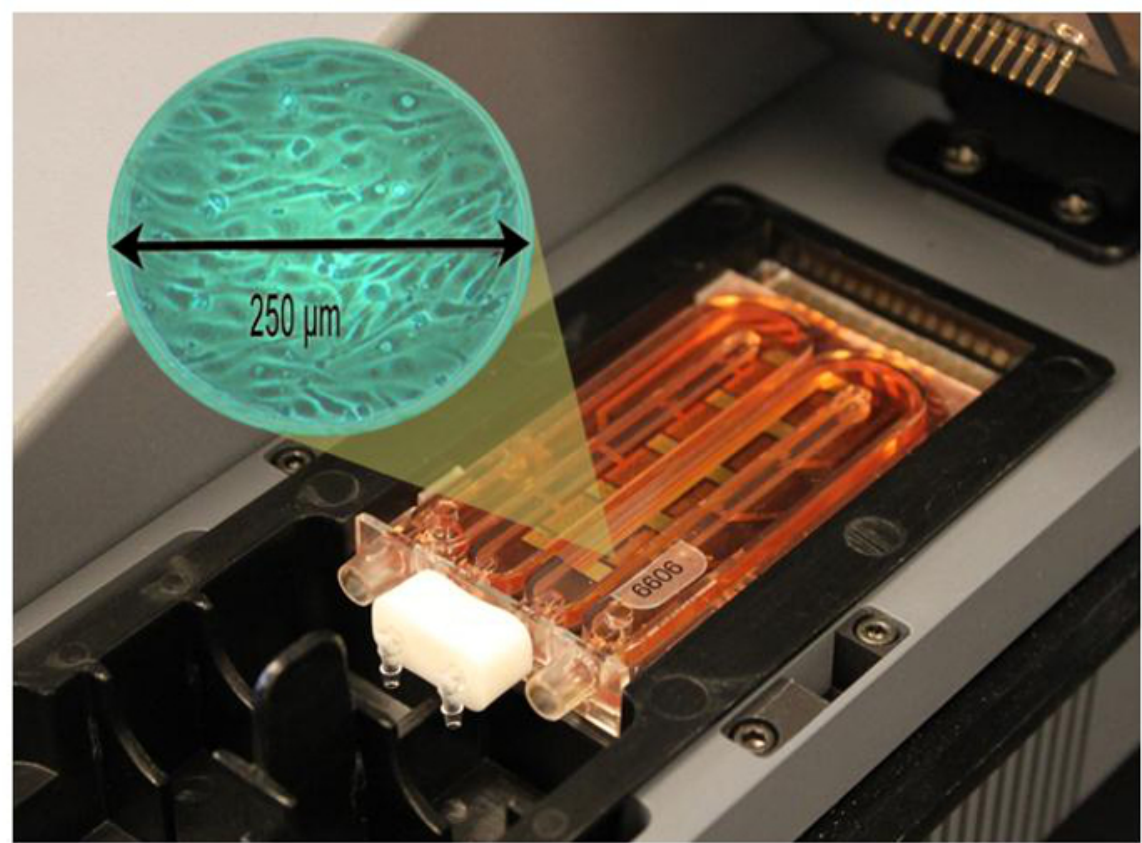

Figure 2: Fluidic Biochip in ECIS Reader. Magnified area shows a confluent monolayer of RTgill-W1 cells on a single sensing electrode. Please click here to view a larger version of this figure. 


\section{Preparation of Test Materials}

NOTE: In order to prepare the biochips for testing, several confluent flasks of RTgill-W1 cells need to be ready. A good estimate of the number of flasks needed is one confluent T175 flask for 16 biochips to be seeded.

1. Perform the following steps in a class II biological safety cabinet (biohood) using aseptic technique. Use $70 \%$ ethanol for disinfecting the biohood and any materials placed in the hood.

1. Prepare fibronectin substrate for the fluidic biochips by thawing a $1 \mathrm{mg}$ vial of fibronectin and diluting in $100 \mathrm{ml}$ of sterile L-15 media for a concentration of $10 \mu \mathrm{g} / \mathrm{ml}$. Freeze in $40 \mathrm{ml}$ aliquots in sterile $50 \mathrm{ml}$ conical polypropylene tubes at $-20^{\circ} \mathrm{C}$. Thaw at room temperature several hours prior to seeding the biochips. Once thawed, do not refreeze.

2. Prepare cell culture media by adding $50 \mathrm{ml}$ of fetal bovine serum, $5 \mathrm{ml}$ of $200 \mathrm{mM}$ an L-alanyl-L-glutamine supplement, and $5 \mathrm{ml}$ of a penicillin/streptomycin solution ( 10,000 units penicillin/ml and $10,000 \mu \mathrm{g}$ streptomycin/ml) stock to $500 \mathrm{ml}$ of $\mathrm{L}-15 \mathrm{media}$. This will yield $560 \mathrm{ml}$ of cell culture media containing $9 \%$ serum. Refrigerate.

Note: This will be the complete cell culture media used for the culture flasks and the biochips.

2. Powdered Media Vials

1. Prepare ahead of time 0.1 dram snap-cap vials containing $60 \mathrm{mg} \pm 0.5 \%$ of $\mathrm{L}-15 \mathrm{ex}$ powder using an automated powder dispenser. Label the vials with the date the powder was dispensed and refrigerate vials (in quantities of 50 ) in recloseable metalized poly bags; each containing three $1 \mathrm{~g}$ silica gel desiccation packs.

Note: L-15ex powdered media vials can be made and stored for up to 9 months in advance of testing.

3. Make a solution of $100 \mathrm{ml} 20 \%$ bleach by diluting household bleach with deionized (DI) water. Estimate that $5 \mathrm{ml}$ of bleach solution will be needed for each biochip.

4. Make biochip tubing assemblies by cutting $27 \mathrm{~mm}$ sections of autoclavable biocompatible tubing ( 2 sections for each biochip to be seeded) and fit both ends of the tube with polycarbonate slip luer fittings. Place tubing assemblies in an autoclavable bag and autoclave for 8 min at $134^{\circ} \mathrm{C}$. Also autoclave biochip plugs ( 2 per biochip) in a separate bag at the same settings.

5. Autoclave DI water for $30 \min$ at $121^{\circ} \mathrm{C}$. Note: This water will be used for rinsing biochips after seeding. Estimate that $10 \mathrm{ml}$ will be needed for each biochip. Note: The actual volume of each biochip channel is $2 \mathrm{ml}$, but $5 \mathrm{ml}$ of sterile water is rinsed through each channel after removal of bleach solution.

6. Make syringe injection tubing assemblies by cutting $27 \mathrm{~mm}$ sections of biocompatible tubing and attaching male slip luer fittings to both ends of the tubing. Place tubing assemblies in a paper heat-seal sterilization pouch and autoclave for $8 \min$ at $134^{\circ} \mathrm{C}$.

\section{Fluidic Biochip Seeding Procedure}

Note: Perform all procedures where the biochips or the media is handled in a class II biological safety cabinet using aseptic technique.

1. Twenty-four hr prior to scheduled seeding, remove the biochips from manufacturer packaging in the biohood and place in sterilized plastic instrument cases.

2. Sterilize the biochips using a $20 \%$ bleach solution as follows

Note: Historically, this bleaching procedure has prevented fungal growth in the biochips during long-term storage in the event that the plasma sterilization of the biochips done by the manufacturer was not effective.

1. Using a $20 \mathrm{ml}$ sterile syringe with a syringe injection tubing assembly attached and working in the biohood, inject $2 \mathrm{ml}$ of the $20 \%$ bleach solution into each channel of the biochip. Allow the biochips to sit for $1 \mathrm{hr}$ with the bleach solution.

2. After one hour, vacuum aspirate the bleach solution from both channels using a sterile male slip luer assembly attached to the vacuum suction tubing. Use one of the biochip tubing assemblies as a drain when rinsing the biochips.

3. Using a sterile $20 \mathrm{ml}$ syringe attached to a sterile syringe injection assembly, flush each channel of the chip with $5 \mathrm{ml}$ of sterile water, allowing the excess water to drain into a container in the biohood. Then vacuum-aspirate off the water as just described for the bleach and place the biochips back into the plastic instrument cases and leave in the biohood until seeded with cells the following day.

3. Sixty min prior to seeding the biochips, inject $2 \mathrm{ml}$ of the $10 \mu \mathrm{g} / \mathrm{ml}$ fibronectin solution into each channel of the biochip. Leave the biochips in the biohood for $60 \mathrm{~min}$, and then vacuum aspirate off the fibronectin (as described in step 2.2.3) before seeding the biochip with cells. Place two sections of the sterile biochip tubing assemblies (refer to section 1.4) on the ports of the biochips.

4. Trypsinize one confluent RTgill-W1 T175 flask for every 16 biochips using procedures outlined in the American Type Culture Collection (ATCC) product description sheet ${ }^{16}$.

1. Aspirate off the media from the confluent flask(s) of cells.

2. Rinse the cell layer with $15 \mathrm{ml}$ of PBS and then aspirate off.

3. Add $6 \mathrm{ml}$ of trypsin/EDTA to the cell layer in each T175 flask and allow cells to trypsinize for $\sim 5 \mathrm{~min}$.

4. Add $15 \mathrm{ml}$ of complete $\mathrm{L}-15$ cell culture media to each flask to stop trypsinization.

5. Combine the cell suspensions in a sterile disposable container.

Note: Container size can vary from 150-500 ml, dependent upon the number of biochips being seeded. Estimate that $5 \mathrm{ml}$ of cell suspension will be needed per biochip. 
5. Remove $\sim 1 \mathrm{ml}$ of the cell suspension and place into a microcentrifuge tube for counting. Using a brightfield microscope with a $10 \mathrm{X}$ objective and a hemocytometer, count a $10 \mu \mathrm{l}$ aliquot of the cells and calculate the volume of complete L-15 cell culture media needed to attain a cell suspension of $2.5 \times 10^{5} \mathrm{cells} / \mathrm{ml}$.

Note: If using the cell suspension to seed flasks to continue the culture, this would be the point to do so. Adjust the cell suspension concentration using complete $\mathrm{L}-15$ cell culture media.

6. Using a sterile $20 \mathrm{ml}$ syringeattached to a sterile syringe injection tubing assembly (see section 1.6 ), inject $2.5 \mathrm{ml}$ of the cell suspension into the outer port of each channel of the biochip (i.e., the ports that do not have the tubing attached), allowing some of the extra cell suspension to flow out of the tubing into a waste container in the biohood.

Note: This will ensure that the entire channel and attached tubing will be full of the cell suspension.

1. Create an enclosed loop for each biochip channel by inserting the free end of the hose with the luer fitting into the outer ports for each channel.

2. Wipe any excess media off of the closed loops with a paper towel moistened with $70 \%$ ethanol and place the biochips back in the plastic box in a $20^{\circ} \mathrm{C}$ incubator. Give each biochip a unique identifying number.

7. On days 4 and 7 , remove the biochips from the $20^{\circ} \mathrm{C}$ incubator and replenish the media in all of the biochips with temperature-equilibrated complete L-15 cell culture media. Follow the same procedure as in step 2.6 except use just L-15 cell culture media instead (no cell suspension). Place the biochips back in the $20^{\circ} \mathrm{C}$ incubator after the day 4 feeding.

1. After the day 7 feeding, remove and discard the hoses from the chips and insert the autoclaved drain plugs in the biochips.

2. Place the biochips in a box in a $6{ }^{\circ} \mathrm{C}$ incubator until used for testing.

Note: The chips can be stored at refrigerated temperatures for up to 9 months and are still viable for testing in the ECIS readers.

\section{ECIS Testing with Biochips}

1. Prepare test chemicals if using. (See Brennan, et al., $2012^{7}$ for preparation of test chemicals).

2. Remove ECIS reader and test supplies from the carrying case. Remove a prepared biochip from the $6{ }^{\circ} \mathrm{C}$ incubator. Place the biochip on a paper towel. Turn on the ECIS reader.

3. Using $10 \mathrm{ml}$ syringes, dispense $10 \mathrm{ml}$ of control water into a labeled 0.5 ounce clear plastic control jar and $10 \mathrm{ml}$ of the test sample into a labeled 0.5 ounce clear plastic test jar.

Note: 1) Be sure to remove bubbles for an accurate measurement. 2) The syringes and jars are color-coded; blue for control and red for test.

4. Remove two powdered media vials from the foil bags. Open one of the powdered media vials (use multipurpose tool if needed) and pour entire contents of one vial into the jar with control water, dropping the entire vial into solution as well. Repeat this procedure with the test jar. Cap and shake the jars to ensure that the powder is dissolved.

5. Fill each of the colored $10 \mathrm{ml}$ syringes with $9 \mathrm{ml}$ of either control (blue syringe) or test (red syringe) solutions from respective vials. Remove air bubbles from syringes.

6. Remove the plugs from the biochip ports and attach the drain.

7. Place the biochip into the removable plastic tray in the ECIS reader and close the lid.

8. Attach filled syringes to the outer biochip ports and attach the syringe plunger.

9. From the main screen, select "NEXT" to initiate pre-test.

Note: Reader software will check impedances. If impedances are within range set by the user (usually between 1,000 and 3,000 ohms) the screen will register "Cartridge Passed" as indicated in Figure 3, and instruct the user to select "Next" and the software will proceed to step 3.10). If the impedances are not within the set range because of a defective biochip or faulty connection of the biochip to the reader (usually due to a misalignment of the electrodes), then the screen will register "Cartridge Failed" and the user will have the option to either "Abort" or "Verify" the test.

1. Select "Abort" to go back to step 3.9). Select "Verify" to proceed to step 3.10) after receiving a "Cartridge Passed" message and selecting "Next".

Note: It is best to take the biochip out and visually inspect it for defects or leaking if a "Cartridge Failed" message is received before proceeding with a new biochip.

\section{Result CARTRIDGE PASSED}

Impedance check passed, press Next to continue.

$\begin{array}{llll}\text { Control } & & \text { Sample } \\ \text { CE1 2000 } & \text { SE1 } & 2001 \\ \text { CE2 1998 } & \text { SE2 } & 2001 \\ \text { CE3 2003 } & \text { SE3 } & 1999 \\ \text { CE4 2003 } & \text { SE4 } & 2000\end{array}$

Figure 3: ECIS Reader Screenshot of a Biochip with Acceptable Impedance Readings. The screenshot shows initial impedance readings in ohms of each of the 4 control electrodes (CE) and 4 test sample electrodes (SE) within the fluidic biochip. Please click here to view a larger version of this figure. 
10. When prompted by the reader, enter sample information using a soft keyboard and then select "Accept" when finished. Note: The ECIS reader software will automatically stamp each dataset with the date, time and other information entered by the user; such as the biochip number, and the type of chemical and concentration. Two min of impedance data will be collected from the inserted biochip and an on-screen timer will count-down time.

11. After two min when prompted by on-screen instructions that are flashing within a red box, hit "NEXT". When prompted by a flashing green box to "Inject samples now", inject the control and test media from the attached syringes simultaneously into the biochip channels. Leave the syringes in place on the biochips when finished.

Note: Impedance values will be collected once per minute for $60 \mathrm{~min}$. If the ECIS reader software determines that the treatment channel is statistically different from the control channel at any point between 10 and 60 min after the start of test, then the on-screen display will indicate that the sample is "Contaminated". If the treatment is not different from the control channel, then the screen will indicate "No Contamination Detected" at the end of the test run.

12. Record test results as contaminated or not contaminated for each sample.

13. At the end of the test run, remove and discard the biochip. Rinse and air-dry the syringes, test vials and removable plastic tray which housed the biochip during the tests.

Note: The ECIS reader has 4 GB of onboard storage for the operational software, control models and the test files generated from running a test. This allows for several thousand test files to be stored on the reader. Files can be retrieved with a USB jump drive and transferred to a computer for further analysis for research purposes if desired.

\section{Representative Results}

The ECIS technology described in this paper underwent testing at the US Environmental Protection Agency (USEPA)-sponsored Technology Testing and Evaluation Program (TTEP). Thirteen chemicals were selected for testing as representatives of a broad spectrum of toxic industrial compounds that could be possible contaminants of drinking water. During the testing, 9 of the 13 were detected by ECIS within an hr at concentrations that are relevant to human health ${ }^{8}$. Table 1 illustrates the results of this contaminant testing. Figure 4 is representative of what a "Contaminated" result would look like on the ECIS reader screen. For the most part, cellular impedances decreased for contaminated samples as compared to controls. Occasionally, certain compounds may cause an increase in impedance.

Also summarized in Table 1 is the clean water testing. Forty clean water samples were run and no contamination was detected in any of the samples (see Figure 5) for a representative screen shot of "No Contamination Detected".

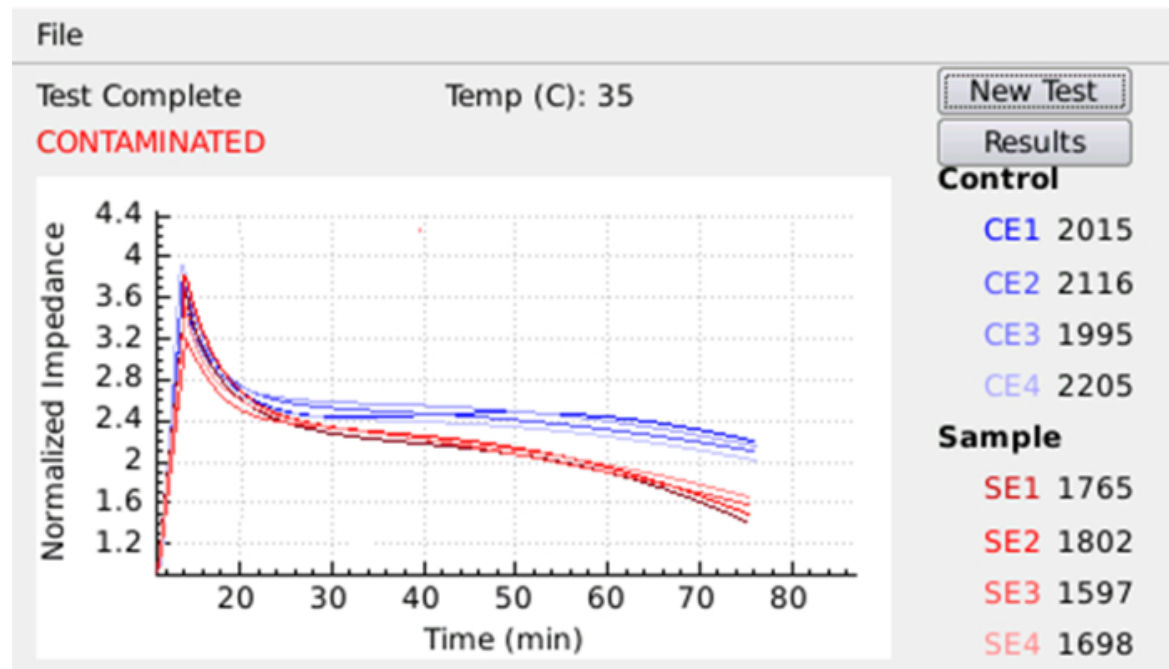

Figure 4: ECIS Reader Screenshot of a "Contaminated" Water Sample. An example of normalized impedance graphics and results from a water sample that was contaminated. Blue lines represent normalized impedances of each of the control electrodes; red lines represent normalized impedances of each of the test sample electrodes. Please click here to view a larger version of this figure. 
File

\section{Test Complete \\ NO CONTAMINATION DETECTED \\ Temp (C): 35}

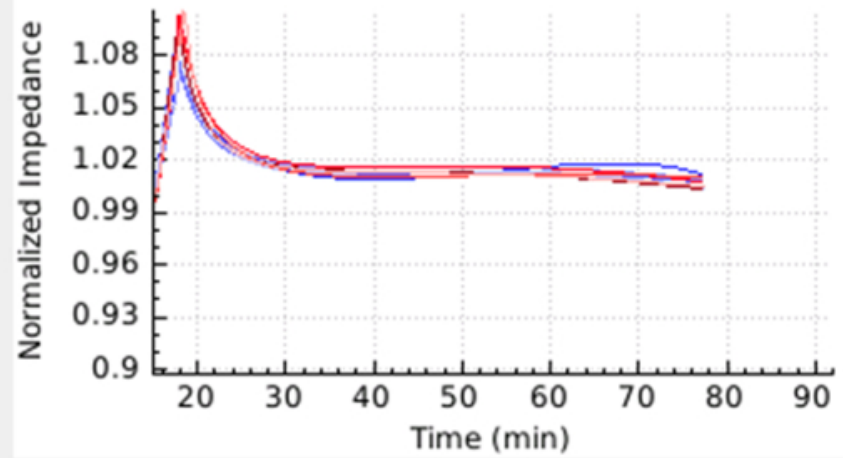

Positive Control

\section{Control}

CE1 2260

CE2 2077

CE3 2376

CE4 2591

Sample

SE1 2105

SE2 2013

SE3 2477

SE4 1979

Figure 5: ECIS Reader Screenshot of a "No Contamination Detected" Water Sample. An example of normalized impedance graphics and results from a water sample that was not contaminated. Blue lines represent normalized impedances of each of the control electrodes; red lines represent normalized impedances of each of the test sample electrodes. Please click here to view a larger version of this figure.

\begin{tabular}{|c|c|c|c|}
\hline Category & Contaminant & Concentration Tested $(\mathrm{mg} / \mathrm{L})^{1}$ & $\begin{array}{l}\text { Detected } \leq 1 \text { hour } \\
n=4 / 4 \text { chips }\end{array}$ \\
\hline \multirow[t]{8}{*}{ Pesticides } & Aldicarb & 0.17 & no \\
\hline & $\begin{array}{l}\text { Arsenic (sodium } \\
\text { arsenite) }\end{array}$ & 4.5 & yes \\
\hline & $\begin{array}{l}\text { Azide (sodium } \\
\text { azide) }\end{array}$ & 46.7 & yes \\
\hline & Fenamiphos & 0.56 & no \\
\hline & Methamidophos & 1.4 & no \\
\hline & Methyl parathion & 33.6 & yes \\
\hline & $\begin{array}{l}\text { Paraquat } \\
\text { (dichloride) }\end{array}$ & 4.6 & no \\
\hline & $\begin{array}{l}\text { Pentachlorophenate } \\
\text { (sodium) }\end{array}$ & 71.9 & yes \\
\hline \multirow{5}{*}{$\begin{array}{l}\text { Industrial } \\
\text { Chemicals }\end{array}$} & Ammonia & 924 & yes \\
\hline & $\begin{array}{l}\text { Copper (copper II } \\
\text { sulfate) }\end{array}$ & 103 & yes \\
\hline & Cyanide (sodium) & 14 & yes \\
\hline & Mercury (chloride) & 24.7 & yes \\
\hline & Toluene & 444 & yes \\
\hline Clean Water ${ }^{2}$ & none & NA & no \\
\hline
\end{tabular}

\section{Table 1: Contaminants in Water Samples Detected by ECIS.}

\section{Discussion}

The ECIS technology performed well in a laboratory setting and was able to detect potential water contaminants at concentrations that are relevant to human health. The portability and packaging of the technology makes it conducive to field use.

Critical steps in the protocol for the success of the technology are as follows: 1) Maintain aseptic conditions during culture, seeding, and feeding of the biochips, 2) Keep the seeded biochips in refrigerated conditions until ready for testing since the RTgill-W1 cells will not survive very long once they are subjected to temperatures above $25^{\circ} \mathrm{C}, 3$ ) Accurately weigh the L-15ex in the powdered media vials and accurately measure the water samples to avoid producing false positives, which can be caused by a shift in the osmolality of media rather than sample toxicity, 4) Follow user instructions on the ECIS screen for running the tests. The software in the reader will alert the user if a biochip is unacceptable for testing 
(based on initial impedance readings) when the biochip is first inserted into the reader. If the impedance levels are unacceptable for testing, the software will not allow the user to proceed with testing until a new biochip is used. Reasons for unacceptable impedance readings are usually due to a slight misalignment of the biochip electrodes with the ECIS reader pins or fluid leakage along one of the gluing edges of the biochip.

There are some limits to this technology because the ECIS sensor has only been tested with drinking water and not with surface water. The RTgill-W1 cells that are on the biochip cannot tolerate freezing or temperatures much above $25^{\circ} \mathrm{C}$ for prolonged periods of time (time frame can be from hours to days dependent upon the temperature. The biochips function best in a temperature range from refrigerated to room temperature ${ }^{7}$. They are ready for immediate use, however, right after being removed from cold storage. Portable cold storage containers are currently used by Army personnel in the field for temperature-sensitive supplies. These same containers can be used for seeded biochip transport.

Another limit to this technology is that even though it is a broad-band toxicity sensor, it does not respond well, if at all, to cholinesterase-inhibiting compounds, such as some pesticides. To fill this capability gap, the ECIS sensor is designed to be used in conjunction with a commercially available rapid pesticide test assay when testing water samples in order to provide the user with a broader range of toxicity testing. The kit is a rapid enzymatic assay designed to detect organophosphate and carbamate pesticides within 30 min.

The ECIS sensor complements the WQAS-PM (Water Quality Analysis System - Preventative Medicine) field water test system, currently used by military preventative medicine personnel to detect, arsenic, lead, or cyanide in a drinking water sample. Although the ECIS sensor will not identify what the contaminant is, it will indicate if certain metals or organic compounds are present, indicating that the water may not be suitable for human consumption. The ECIS test results are available within an hr. The water samples can then be sent out for further analysis for identification of the contaminant if there is a positive test result.

As described above, the ECIS reader is designed to be part of a system that includes a separate enzymatic ACE kit in order to cover a broad spectrum of contaminant detection. Both of these readers are being packaged in a sturdy case for field transport for field use by soldiers.

\section{Disclosures}

Opinions, interpretations, conclusions, and recommendations are those of the authors and are not necessarily endorsed by the U.S. Army. Citations of commercial organizations or trade names in this report do not constitute an official Department of the Army endorsement or approval of the products or services of these organizations. Authors Linda M. Brennan and Mark W. Widder, both of the US Army Center for Environmental Health Research, declare that they have no competing financial interests. Michael Mayo, Michael McAleer and Alex Greis are employees of Nanohmics that produces the disposable biochips and instruments used in this Article.10251980

\section{Acknowledgements}

This work was supported by the US Army Medical Research and Materiel Command and by the Small Business Innovation Research and Small Business Technology Transfer program; Contract No. W81XWH-13-C-0093. We would like to thank Dr. Lucy Lee at the University of Fraser for being our RTgill-W1 cell culture mentor, and to acknowledge Dr. Niels Bols of Waterloo University for the development of the RTgill-W1cell line.

\section{References}

1. Pancrazio, J.J., Whelan, J.P., Borkholder, D.A., Ma, A., Stenger, D. A. Development and application of cell-based biosensors. Ann. Biomed. Eng. 27, 697-711, (1999).

2. States, S., Scheuring, M., Kuchta, J., Newberry, J., Casson, L. Utility-based analytical methods to ensure public water supply security. J. Am. Water Works Assoc. 95, 103-115, (2003).

3. Kelly, T., Baxter, W., McCauley, M., Koglin, E. Testing of Screening Technologies for Detection of Toxic Industrial Chemicals in All Hazards Receipt Facilities. EPA/600/R-08/034, Washington, DC, pp. 1-25 (2008).

4. van der Schalie, W.H., James, R.R., Gargan, T.P., II. Selection of a battery of rapid toxicity sensors for drinking water evaluation. Biosens. Bioelectron. 22, 18-27, (2006).

5. luga, A., Lerner, E., Shedd, T.R., van der Schalie, W.H. Rapid responses of a melanophore cell line to chemical contaminants in water. J. Appl. Toxicol. 29, 346-349, (2009).

6. Curtis, T.M., et al., Suitability of invertebrate and vertebrate cells in a portable impedance-based toxicity sensor: temperature mediated impacts on long-term survival. Toxicol. In Vitro 27, 2016-2066, (2013).

7. Brennan, L.M., Widder, M.W., Lee, L.E.J., van der Schalie, W.H. Long-term storage and impedence-based water toxicity testing capabilities of fluidic biochips seeded with RTgill-W1 cells. Toxicol In Vitro. 26, 736-745, (2012).

8. Widder, M.W., Brennan, L.M., Hanft, E.A., Schrock, M.E., James, R.R., van der Schalie, W.H. Evaluation and refinement of a field-portable drinking water toxicity sensor and a fluidic biochip. J. Appl. Toxicol. (2014).

9. O'Shaughnessy, T.J., Gray, S.A., Pancrazio, J.J. Cultured neuronal networks as environmental biosensors. J. Appl.Toxicol. 24, 379-385, (2004).

10. Eltzov, E., Marks, R.S. Whole-cell aquatic biosensors. Anal. Bioanal. Chem. 400, 895-913, (2011).

11. Giaever, I., Keese, C.R., A morphological biosensor for mammalian cells. Nature. 366, 591-592, (1993).

12. Curtis, T.M., et al.,. A portable cell-based impedance sensor for toxicity testing of drinking water. Lab on a Chip 9, 2176-2183 (2009).

13. Xiao, C., Luong, J.HT. Assessment of cytotoxicity by emerging impedance spectroscopy. Toxicol. .Appl. Pharmacol. 206 (2), 102-112, (2005).

14. Xing, J.Z., Zhu, L., Gabos, S., Xie, L. Microelectronic cell sensor assay for detection of cytotoxicity and prediction of acute toxicity. Toxicol. In Vitro. 20, 995-1004, (2006)

15. Lee, L.E.J., Dayeh, V.R., Schirmer, K., Bols, N.C., Applications and potential uses of fish gill cell lines: examples with RTgill-W1. In Vitro Cell. Develop. Biol.- Animal. 45, 127-134, (2009). 
16. American Type Culture Collection (ATCC), Manassas, VA., RT-gill-W1 (ATCC CRL-2523) Culture Method. https://www.atcc.org/ ATCCAdvancedCatalogSearch/ProductDetails/tabid/452/Default.aspx? ATCCNum=CRL-2523\&Template=cellBiology\#aPropba73c (2015). 